\title{
Advancing entrepreneurial career success: the role of passion, persistence, and risk-taking propensity
}

\author{
Hussein-Elhakim Al Issa
}

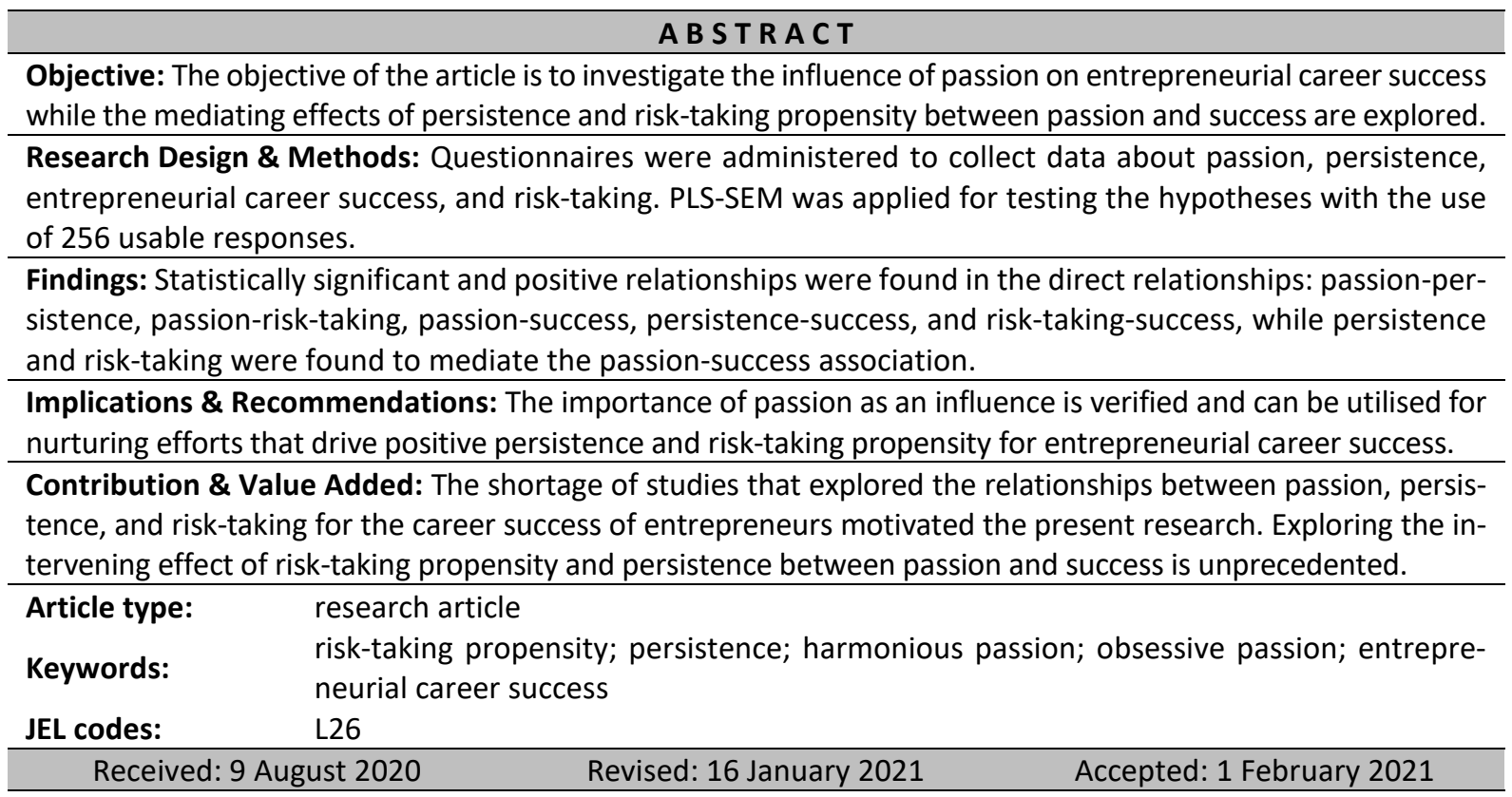

Suggested citation:

Al Issa, H.-E. (2021). Advancing entrepreneurial career success: the role of passion, persistence, and risk-taking propensity. Entrepreneurial Business and Economics Review, 9(2), 135-150. https://doi.org/10.15678/EBER.2021.090209

\section{INTRODUCTION}

Entrepreneurship is believed to be an important engine of the collective wellbeing and a remarkable mechanism of economic progress (GEM, 2020). Passion is part of the theory of positive psychology and so has a deep influence on people's psychological and behavioural activities (Stroe et al., 2018; Thorgren et al., 2015). Presently, scholars are applying passion theory to understand entrepreneurial behaviour. Passion theory can be used to explain entrepreneurial behaviour because passion is a central characteristic to have for inspiration (Montiel-Campos, 2018). By persevering and tirelessly following goals, entrepreneurs achieve success (Al Issa, 2020; Milanesi, 2018). Attaining entrepreneurial success requires years of unyielding effort. GEM (2020) report shows that most economies have higher levels of early-stage entrepreneurship than established ventures, with a distinct delay in transition which might indicate difficulties in transitioning these into established businesses. A lot of research has examined the factors behind working towards the attainment of career goals and giving up on them (Efobi \& Okoh, 2018; Karaman et al., 2019; Mooradian et al., 2016; Poczwardowski et al., 2014). A blend of such neglected factors is passion, persistence, and risk-taking propensity. 
The reason behind the need to study entrepreneurial career success (ECS) as a proxy to performance is the trouble in detaching a career from business success for entrepreneurs. That is because entrepreneurs decide what success means to them. Besides financial attainment, success can be measured with satisfaction and achievement outcomes (Salisu et al., 2020; Wach et al., 2018). Passionate and persistent people are absorbed by what they do and desire it tenaciously until they succeed in it (Cardon, 2013; Baum \& Locke, 2004). The literature study has revealed three factors that are generally accepted to represent entrepreneurial career success well, namely, career satisfaction, perceived career achievement, and perceived financial attainment (Lau et al., 2007; Wach et al., 2018).

In this research, ECS is a subjective construct that denotes less tangible perception of what is important to achieve in career success (McDonald \& Hite, 2008). The first dimension of the ECS construct is career satisfaction which means how much the person likes his or her career to the point of resisting to take on other means of livelihood (Priyono, 2017; Kautonen \& Palmroos, 2010). The second dimension is perceived career achievement which is viewed as worthwhile career attainments (Lau et al., 2007). The last dimension is perceived financial attainment, which is a valuable financial gain that marks the highpoint of an entrepreneurial career, especially when it exceeds others' (Lau et al., 2007).

Passion takes the form of a powerful tendency to devote a great deal of time and energy, i.e., persistence to reach high degrees of performance required to succeed in business ventures (Vallerand et al., 2003). When failures inevitably happen, what keeps an entrepreneur from giving in is their passion, as revealed by prior studies proving that passion impacts persistence (Al Issa et al., 2019; Cardon et al., 2015; Liang et al., 2018). Persistence is assumed to be related to improved performance directly (Duening et al., 2019; Wu et al., 2007), and indirectly as theorised in its association with pursuing difficult growth goals and venture survival and growth (Baum et al., 2001; Chang et al., 2007; Gartner et al., 1991). This indicated an indirect influence between passion and its associated performance.

Likewise, passion has been theorised as related to risk-taking as it is attached to the formulation of fresh strategies to allow business growth (Chen et al., 2015; Santos et al., 2020). At the same time, risk-taking as part of entrepreneurial orientation (EO) is related to performance (Adomako et al., 2016; Pratono, 2018). Besides, insights into the associations between passion, persistence, and risk-taking with a nascent outcome like entrepreneurial career success could aid in determining if there is the best equilibrium or a practical game-changer for the variables outside which their impact is harmful instead of being favourable for entrepreneurs. Given the discussion above, we aim to realize the research objectives below:

1. To investigate the connection between entrepreneurial passion (EP) and entrepreneurial career success (ECS).

2. To test the mediating effect of persistence (P) on the relationship between EP and ECS.

3. To determine the mediating effect of risk-taking propensity (RTP) on the relationship between EP and ECS.

It would be particularly interesting to verify in the current study a novel, complex, and possibly negative relationship between obsessive and harmonious passion with entrepreneurial career success while exploring potential mediators like persistence and risk-taking. The study sheds light on the value of connections that entrepreneurs might have beyond the sphere of business should they not monitor and rein in their entrepreneurial passions.

Malaysia has developed extensive initiatives to boost entrepreneurial education and skills and experts point out that physical infrastructure and entrepreneurial opportunities are abundant (GEM, 2018; Avvisati et al., 2020). In Malaysia, the establishment of a new business is deemed a suitable way to become wealthy yet not more than $50 \%$ think it should be an attractive career choice (GEM, 2010). That is most likely because attaining entrepreneurial career success normally requires years of unyielding effort. This makes Malaysia a model prototype to examine the impact of passion, persistence, and risk-taking on entrepreneurial success.

This research article starts by reviewing relevant anecdotal and empirical evidence to provide understanding for the concepts studied. It is then followed by sections that discuss all the methodologies and analysis techniques applied in the research. Finally, a discussion of findings, implications, 
and conclusion are laid out. This last section also suggests possible future research work arising from this study.

\section{LITERATURE REVIEW}

Empirical evidence containing entrepreneurial passion is expanding around the world (Cardon et al., 2017; Murnieks et al., 2020; Santos et al., 2020). The impact passion has on entrepreneurial behaviour can be derived from the leading work by Cardon and Kirk (2013), Murnieks et al. (2014), and Vallerand et al. (2003). The proposed model in the present research is inspired by the theoretical framework outlined in lyortsuun et al. (2019) linking passion as an antecedent to performance and mediated by behaviour. The self-determination theory (SDT) (Deci \& Ryan, 2012), identity theory (Burke \& Reitzes, 1981, 1991), and Social Cognitive Career Theory (SCCT) (Brown et al., 2011), which is based on Bandura's (1986) social cognitive theory (SCT), support the current study's model which investigates the impact of passion on entrepreneurial career success as well as the intervening effects of persistence and risk-taking propensity on the passion-success association (Figure 1).

The self-determination theory (SDT) claims that people engage in activities in the hope of growing psychologically and satisfying the basic psychological needs of autonomy competence and relatedness (Vallerand, 2016). SDT suggests that individuals would rather feel in-charge of their actions, and if something makes a formerly liked activity feel like a requirement instead of a chosen task then it will weaken their motivation. This is not evident as much in work as it is in the leisure activities of our own choice. A limited few of these activities start to resonate with our core until they become part of our newly determined identity.

SDT indicates that certain activities trigger feelings of social acceptance from the environment and self-esteem from personality. There are two ways individuals bring things inside them: autonomous and controlled. If the social environment is supportive of the need for autonomy, then it leads to harmonious passion. If the social environment is controlling, then it leads to obsessive passion. People with obsessive passion show inflexible tenacity for activities owing to an intense desire to take part in the activity they see as meaningful and pleasurable. On the other hand, harmonious passion displays flexible persistence toward the activity due to an independent internalisation into the self. It produces a drive to endorse the activity and engage in it willingly. For entrepreneurs, this passion takes the form of a powerful tendency to devote a great deal of time and energy in the form of persistence, in doing all the entrepreneurial activities that they are passionate about.

According to identity theory, self-defining activities that people have passion for hold meaning in one's identity (Cardon \& Kirk, 2015). Entrepreneurial passion is aroused because certain ventureoriented activities are meaningful and significant to the identity. As a result, an entrepreneur exhibits persistence in activities that substantiate and confirm the identity activated by passion. Positive psychology theory also supports the notion that people continue doing activities that invoke feelings that put them in a positive emotional state (Stroe et al., 2018; Thorgren et al., 2015). These deeply meaningful activities bolster role identity and ease the risk of identity threats (Cardon et al., 2009).

Finally, the Social Cognitive Career Theory (SCCT) asserts that desire and likelihood of reaching an outcome are vital elements when a big change is about to take place, such as embarking on a new venture journey. However, individuals must have cognitive abilities, like passion, persistence, and risk-taking propensity to attain entrepreneurial career success. Outcome expectations are beliefs about the consequences of engaging in desired tasks. For entrepreneurial career success, passion fuels motivation and enriches the welfare and makes sense out of the ordinary life while taking the necessary risks and persisting against all odds. Stronger passion for an activity influences success through heightened initiative, persistence, and risk-taking to guarantee success. 


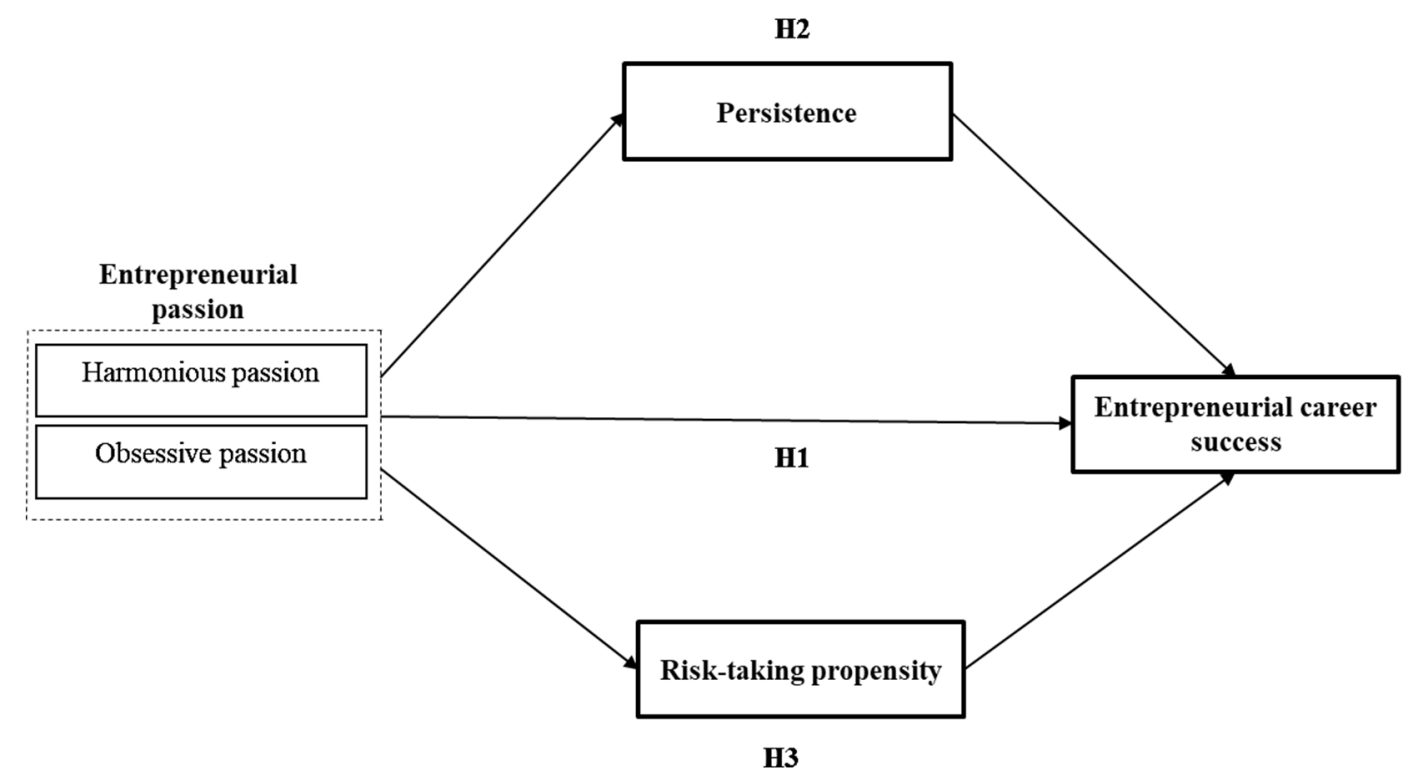

Figure 1. Research Framework

Source: own elaboration.

\section{Passion and entrepreneurial career success}

Entrepreneurial passion is a powerful tendency for entrepreneurial endeavours that people feel strongly about and so spend a good deal of time and energy on (Vallerand et al., 2003). The first dimension of passion are harmonious passions which arise from independent absorption of interest into one's identity that creates a strong desire and individual approval for the venture. The second are obsessive passions which are controlled internalisation that derives from within the self or social pressures connected with the activity. Individuals who have an obsessive passion can therefore end up feeling an irresistible urge to take part in their valuable and pleasurable activity. Still, the entrepreneur might have difficulties focusing on entrepreneurial activities and performing them to the point of successful completion because of the sense of obligatory association now with the expected extrinsic reward.

The success of an entrepreneurial venture hinges on what constitutes success in the entrepreneur's venture and her/his career. Scholars recognized that in addition to monetary gain, there are important and meaningful ways to gauge success that include satisfaction and achievement outcomes (Salisu et al., 2020; Wach et al., 2018). Past studies have identified passion as a predictor of various outcomes and performance directly (Ho \& Pollack, 2014; lyortsuun et al., 2019; Ma et al., 2017; Vallerand, 2008) and indirectly (Baum \& Locke, 2004; Murnieks et al., 2014). Boon et al. (2020) examined the effect of team passion on performance and showed that teams need to be passionate about activities right for a particular stage in venture development. For example, Vallerand et al. (2008) found that harmonious and obsessive passions lead to committing to deliberate practice which impacts sports performance. Another example is the study by Mueller et al. (2017) which revealed a significant link between passion and firm performance. Therefore, in the current study, it is proposed that passion will lead directly to higher performance in the form of entrepreneurial career success. Keeping this discussion in mind, the following three hypotheses are presented, one of which was the main hypothesis for the EP construct and the remaining two were sub-hypotheses formulated for each passion dimension:

H1: Entrepreneurial passion (EP) is positively and significantly related to entrepreneurial career success (ECS).

H1a: Harmonious passion is associated with ECS.

H1b: Obsessive passion is associated with ECS. 


\section{Persistence as a potential mediator}

Persistence has been deemed a necessary characteristic of successful entrepreneurs (Caliendo et al., 2020; Kuratko \& Hodgetts, 2007; Wu, Matthews, \& Dagher, 2007). Entrepreneurial persistence is displayed by an entrepreneur's constant optimistic upkeep of entrepreneurial enthusiasm and endlessly revived vigorous effort in a new business venture in the face of opposing pressures or attractive options. The literature on entrepreneurship persistence offers the widespread notion that persistence is the work of a variety of antecedents. The characteristics of an entrepreneur (Brüderl \& Ziegler, 1992; Caliendo et al., 2014; Cardon \& Kirk, 2015) and attributes of a new business (Fritsch et al., 2007; Chu et al., 2011) are the major factors of persisting.

When entrepreneurs fail, their passion for their business activates their persistence until they achieve success. This is because persistence is the "goal-directed energy sustained over time" (Shane, 2003, p. 268). Prior studies have shown how passion affects persistence and it has been theorised for identity-related reasons and the emotional component of passion (Al Issa et al., 2019; Cardon et al., 2015; Chandler \& Jansen, 1992; Liang et al., 2018).

By the same token, studies show that high performers work on improving skills to become experts and so excel at what they do. Therefore, in the current study, it is proposed that entrepreneurs persist at their ventures until they succeed in it as a career (Vallerand, 2008). Persistence is assumed to be related to improved performance directly (Duening et al., 2019; Wu et al., 2007) and indirectly as theorised in its association with pursuing difficult growth goals and venture survival and growth (Baum et al., 2001; Chang et al., 2007; Gartner et al., 1991). For example, Wu et al. (2007) in a longitudinal study of emerging entrepreneurs in a mid-western state in the USA found that business growth expectations are positively related to entrepreneurial persistence. Given the discussion above, the following three hypotheses are put forth, one of which was the main hypothesis for the persistence construct, and the remaining two were sub-hypotheses formulated for each passion dimension:

H2: Persistence $(P)$ will mediate the effect of EP on ECS.

H2a: $P$ will mediate the effect of harmonious passion on ECS.

H2b: P will mediate the effect of obsessive passion on ECS.

\section{Risk-taking propensity as a potential mediator}

Risk-taking is making decisions to dedicate resources to plans with uncertain outcomes (Anderson et al., 2015). It is important to examine risk-taking propensity (RTP) in the current model because studies analysing entrepreneurial risk-taking often neglect to consider the amassed wealth as an antecedent of this risk (Zahra, 2018). At the individual level, a study by Kollmann et al. (2017) conducted on 104 dyadic entrepreneurial teams found that innovativeness facilitates team performance but also found that diversity in pro-activeness and risk-taking within a team impairs team performance. Moreover, Vallerand et al. (2008) discovered that harmonious passion for dramatic arts has a positive impact on life satisfaction, while obsessive passion is not related to it. A possible explanation is that obsessive passion leads to smaller degrees of satisfaction than a harmonious passion in pursuit of greater outcomes. Since people are risk-averse when positive things happen and risk-seeking when negative ones happen (Bazerman \& Moore, 1994), therefore, the current study proposes to verify the conflicting results for the risk-taking propensity association with performance and the possible mediating role of risk-taking on the passion-success association.

Passion for expanding enterprises is related to creating fresh strategies for business growth (Campos, 2017; Chen et al., 2015; Santos et al., 2020). Also, the RTP dimension is an integral part of the EO construct but it has shown inconsistent results for its relationship with firm outcomes (Musa et al., 2014; Palalic \& Busatlic, 2015; Zhao et al., 2011). For example, Pratono (2018) conducted a study that involved 390 Indonesian SME owner-managers and confirmed the positive RTP-performance association. Moreover, Fairoz et al. (2010) verified that only proactiveness reported a significant positive association with performance but risk-taking or innovativeness did not. Therefore, the present research seeks to investigate the intervening effect of RTP between passion and ECS. Taking into account these arguments, the 
following three hypotheses are presented, one of which was the main hypothesis for the persistence construct, and the remaining two were sub-hypotheses formulated for each passion dimension:

H3: RTP will mediate the effect of EP on ECS.

H3a: RTP will mediate the effect of harmonious passion on ECS.

H3b: RTP will mediate the effect of obsessive passion on ECS.

\section{RESEARCH METHODOLOGY}

\section{Sampling}

Data were collected in person by research assistants from entrepreneurs in three Malaysian northern states, Kedah, Penang, and Perlis. At the outset, 400 questionnaires employing purposive sampling were circulated, only 256 fulfilled the conditions and were employed in the remaining analysis, obtaining a response rate of $64 \%$.

The purposive sampling used took advantage of expert judgment to select non-random elements that represented a cross-section of the population. This ensured that genders and a variety of businesses were represented sufficiently due to their importance in the study (Lavrakas, 2008). Characteristic elements of Malaysian entrepreneurs ensured extra variety in terms of wholesale and retail trade, smaller businesses, newer firms, and gender. Given this subjectivity, this method is considered most appropriate for small samples from a limited geographic area i.e., states in northern Malaysia. The lowest number of respondents was estimated at 119 as also validated with a priori G*Power analysis (Bruin, 2006).

The sample was made up of respondents involved in a variety of businesses. The highest percentage of entrepreneurs were in wholesale and retail trade (36.3\%), followed by varied categories like street hawkers, barbers/beauty salons, and cobblers (14.5\%), and hotels and restaurants (11.7\%). Further, most of the entrepreneurs were females $(55.7 \%, n=144)$, with the majority having fewer than five employees (66.8\%), and their source of capital investment from personal savings (59.7\%). Most of the firms studied were under six years in business (66.4\%), which is in-line with studies that claim new ventures are in a serious developmental phase at some point in their first six years and are deemed start-ups (Shrader, Oviatt, \& McDougall, 2000). Also, the first six years are important because a venture shows its potential for initial performance, such as revenue and an increase in hired employees, whereas in later years these factors may be less pertinent (Hmieleski et al., 2013). In this study, most of the businesses were considered in a major developmental stage as most respondents identified themselves as novice entrepreneurs with under six years in business $(66.4 \% \mathrm{n}=168)$ and the remaining were classed as habitual entrepreneurs (33.6\% n=85) (Hmieleski et al., 2013; Ucbasaran et al., 2001).

\section{Measures}

\section{Entrepreneurial career success}

The entrepreneurial career success was measured against 14 items, categorised under the three dimensions: career satisfaction, perceived career achievement, and perceived financial attainment, which were adopted from Salisu et al. (2019), and by the work of Lau et al. (2007) and Greenhaus et al. (1990). ECS is operationalised as the total positive and desirable outcome individuals have achieved through their career experience (Salisu et al., 2017). The standard five-point Likert-like scale ranging from "strongly disagree" to "strongly agree" was applied and had internal consistency of 0.939.

\section{Entrepreneurial passion}

The entrepreneurial passion was measured using six items, three of which measured harmonious passion and three items measured obsessive passion as adopted from Murnieks et al. (2020) and in accordance with the work by Vallerand et al. (2003) and validated by Marsh et al. (2013). The standard five-point Likert-like scale ranging from "strongly disagree" to "strongly agree" was used and had internal consistency of 0.742 . 


\section{Persistence}

The persistence was measured against five items (Baum \& Locke, 2004; Van Scotter \& Garg, 2019). The five-point Likert scale was used while estimating internal consistency of 0.874 .

\section{Risk-taking propensity}

To measure entrepreneurial risk-taking propensity exclusively, seven items were included (Covin \& Slevin, 1989; Morgan \& Strong, 2003; Tan \& Litschert, 1994; Venkatraman, 1989) that had internal consistency of 0.812 . One of the most debated issues in entrepreneurial orientation is the approach towards its dimensionality (Covin \& Slevin, 1989; Lumpkin \& Dess, 1996; Santos et al., 2020). The current research assumed its multidimensionality as more appropriate to tap the multifaceted nature to explore the possible polarised effects of passion and its mediated prediction of success guiding the selection of the risk-taking propensity.

\section{RESULTS AND DISCUSSION}

The article reports findings and interpretations of the main analyses carried out, namely the exploratory factor analyses, the assessments of measurement and structural models, and hypothesis testing. There were no indications of non-response bias as presented by an independent sample t-test to compare the study's variables. All $p$ values were above 0.05 in the t-test results indicating no difference between responders during the two months of data collection (Pallant, 2013). The output from SPSS was checked for outliers by looking at the Mahalanobis distances for values that are greater than (16.27) the critical chi-square. Three cases were identified and removed from the data set, cases 184, 240 , and 244 , with values $25.3,25.6$, and 21.1, respectively (Tabachnick \& Fidell, 2007).

Table 1. Descriptive statistics and correlations

\begin{tabular}{|l|c|c|c|c|c|c|c|c|}
\hline \multicolumn{1}{|c|}{ Variables } & Mean & SD & $\mathbf{1}$ & $\mathbf{2}$ & $\mathbf{3}$ & $\mathbf{4}$ & $\mathbf{5}$ & $\mathbf{6}$ \\
\hline 1: Gender & 1.56 & 0.50 & & & & & & \\
\hline 2: Years in business & 1.34 & 0.47 & -0.11 & & & & & \\
\hline 3: ECS & 3.89 & 0.70 & 0.05 & $0.26^{* *}$ & 0.01 & & & \\
\hline 4: EP & 4.23 & 0.58 & -0.04 & $0.29^{* *}$ & $0.17^{* *}$ & $0.51^{* *}$ & & \\
\hline 5: $\mathbf{P}$ & 3.71 & 0.64 & -0.02 & $0.17^{* *}$ & $0.17^{* *}$ & $0.53^{* *}$ & $0.56^{* *}$ & \\
\hline 6: RTP & 4.36 & 0.63 & -0.05 & 0.13 & 0.04 & $0.60^{* *}$ & $0.48^{* *}$ & $0.45^{* *}$ \\
\hline
\end{tabular}

Note: $\mathrm{N}=256 .{ }^{* *} p<0.01$

Source: own study.

Pearson correlation is typically used to exhibit the direction and the strength of the relationship between continuous variables (Pallant, 2013). According to the results, correlations were significant between passion, persistence, risk-taking, and success (Table 1 ).

The effects of common method variance were treated by safeguarding the anonymity of the surveyed entrepreneurs, decreasing evaluation fear and clarifying the items by elucidating each indicator. Likewise, Harman's single factor showed the first factor explaining less than $50 \%$ of the total variance as recommended by MacKenzie and Podsakoff (2012). After the retrieval of all the questionnaires, a data cleaning process showed that less than $5 \%$ values were missing per indicator and so these were replaced with SPSS's Expectation-Maximisation function. Normality was established for all variables using the $Q-Q$ plot, which was very close to a straight line and the histogram was nearly bell-shaped, and the de-trended normal Q-Q graphical showed no gathering of points, with the majority accumulating near the zero. Furthermore, VIF (variance-inflated factor) was below 5 , at $1.995,1.583$, and 1.919 , and tolerance values were all above 0.20 , at $0.501,0.632$, and 0.521 for entrepreneurial passion, risk-taking, and persistence, respectively, which indicated that there were no multicollinearity issues among the constructs. 
The PLS-SEM measurement model was carried out for confirmatory factor analysis. All items loadings were retained as their factor loadings were $>0.5$ as presented in Figure 2. Convergent validity via higher AVE was confirmed (Fornell \& Larcker, 1981). Examining the outer models was the first step in evaluating the measurement model. The outputs also showed satisfactory composite reliability limits ranging from 0.825 to 0.947 .

The evaluation of the measurement model began by inspecting the outer model and then the valuation of discriminant validity. The first method to establish discriminant validity was the examination of the cross-loadings of the indicators, which showed all item loadings greater than all cross-loadings with other constructs. Likewise, the Fornell-Larcker's criterion (1981) was met with square roots for all AVEs higher than inter-construct correlations and so discriminant validity at the construct level was also established. Lastly, discriminant validity was also established with the heterotrait-monotrait ratio (HTMT) (Henseler et al., 2015). To assess the structural model, this study adhered to the statistical procedure recommended by Hair et al. (2017). The procedure is composed of six main steps that begin by inspecting collinearity issues via VIF. The results show that all main hypotheses were accepted at $p$ $<0.01$ except for one rejected (Table 2 and Figure 2). The rejected hypothesis $1 \mathrm{~b}$ proposed that obsessive passion was related to success. Interestingly, persistence and risk-taking propensity fully mediated the association between obsessive passion and entrepreneurial career success.

PLS-SEM assessed the model's predictive capability and revealed the $R^{2}$ for success $(0.488,0.479$ $\mathrm{R}^{2}$ Adjusted) and persistence (0.390, $0.385 \mathrm{R}^{2}$ Adjusted); they were deemed moderate and weak, respectively (Cohen, 1988). The assessment of the effect sizes $\left(\mathrm{f}^{2}\right)$ were small at 0.048 for harmonious passion and success, very small at 0.000 for obsessive passion and success, and small at 0.033 for persistence and success, but there was a large effect for risk-taking and success (Kenny, 2016). Next, the $Q^{2}$ values were estimated which was 0.262 (omission distance $D=7$ ) for success, 0.248 for persistence, and 0.121 for risk-taking, indicating predictive relevance of the model. Finally, predictive relevance measured with the effect size $q^{2}$ on success was small at $0.012,0.098,0.019$, and -0.001 and for persistence and risk-taking, harmonious passion, and obsessive passion, respectively (Hair et al., 2017).

The current framework presents entrepreneurial passion as sparking entrepreneurial career success mediated by persistence and risk-taking propensity after controlling for gender and years in business. A parametric multi-group analysis was run using SmartPLS v. 3 to compare the two genders $(F=141, M=112)$ and novice $(n=167)$ and habitual entrepreneurs $(n=85)$ as recommended by Ucbasaran et al. (2001) and Westhead et al. (1998), there was no significant difference found in the variables regarding gender. However, the results showed that EP for habitual entrepreneurs predicted persistence to a significant extent in comparison to novice entrepreneurs $(\beta=0.277$; $\mathrm{t}$-value $=2.914 ; p<$ 0.004). Moreover, there was no significant difference in the mediation of $P$ and RTP on the EP-ECS relationship for both novice and habitual entrepreneurs. This means that the direct effect of habitual was more significant than for novice entrepreneurs. A possible interpretation is that as habitual entrepreneurs gained more experience, they needed to rely more on their passion to persist in their business pursuits to secure entrepreneurial career success.

The initial objective was to investigate the EP-ECS association paralleled by the first hypothesis which showed a significant and positive effect (Table 2). The sub-hypothesis $\mathrm{H} 1$ a that proposed harmonious passion associated with entrepreneurial success was also accepted (standard beta $=0.199, \mathrm{t}-$ statistic $=3.181, p<0.001)$. Previous studies have also demonstrated that passion impacts success $/$ performance (lyortsuun et al., 2020; Murnieks et al., 2014; Vallerand, 2008). However, the sub-hypothesis $\mathrm{H} 1 \mathrm{~b}$ that proposed that obsessive passion is associated with entrepreneurial success was rejected. Obsessive passion can be possessed by an entrepreneur in a position of experiencing an irrepressible impulse to participate in business that they feel vital and pleasing. Still, these same people might have difficulties focusing on entrepreneurial activities and performing to the point of success because of the sense of obligatory association that now exists with the extrinsic reward i.e., financial attainment.

Obsessive passion makes people experience an intense desire to take part in an activity. However, the lack of direct relationship between obsessive passion and success might be due to the agony felt and lower levels of career satisfaction in a destructive spiral process coupled with the pressure of chas- 
ing high performance levels that is typically associated with obsessive passion. This suggests the existence of an indirect relationship between obsessive passion and performance as Vallerand (2008) found, with deliberate practice mediating the relationship. Another reason for the lack of influence of obsessive passion on success is the torn sense of pressure and impulse to succeed combined with a concern and fear of performing poorly. Moreover, entrepreneurial demands like wearing many hats but at the same time maintaining a balanced life for optimal performance is often at odds with the rigidity of obsessive passion that takes over and results in less-than-ideal conditions from lacking versatility.

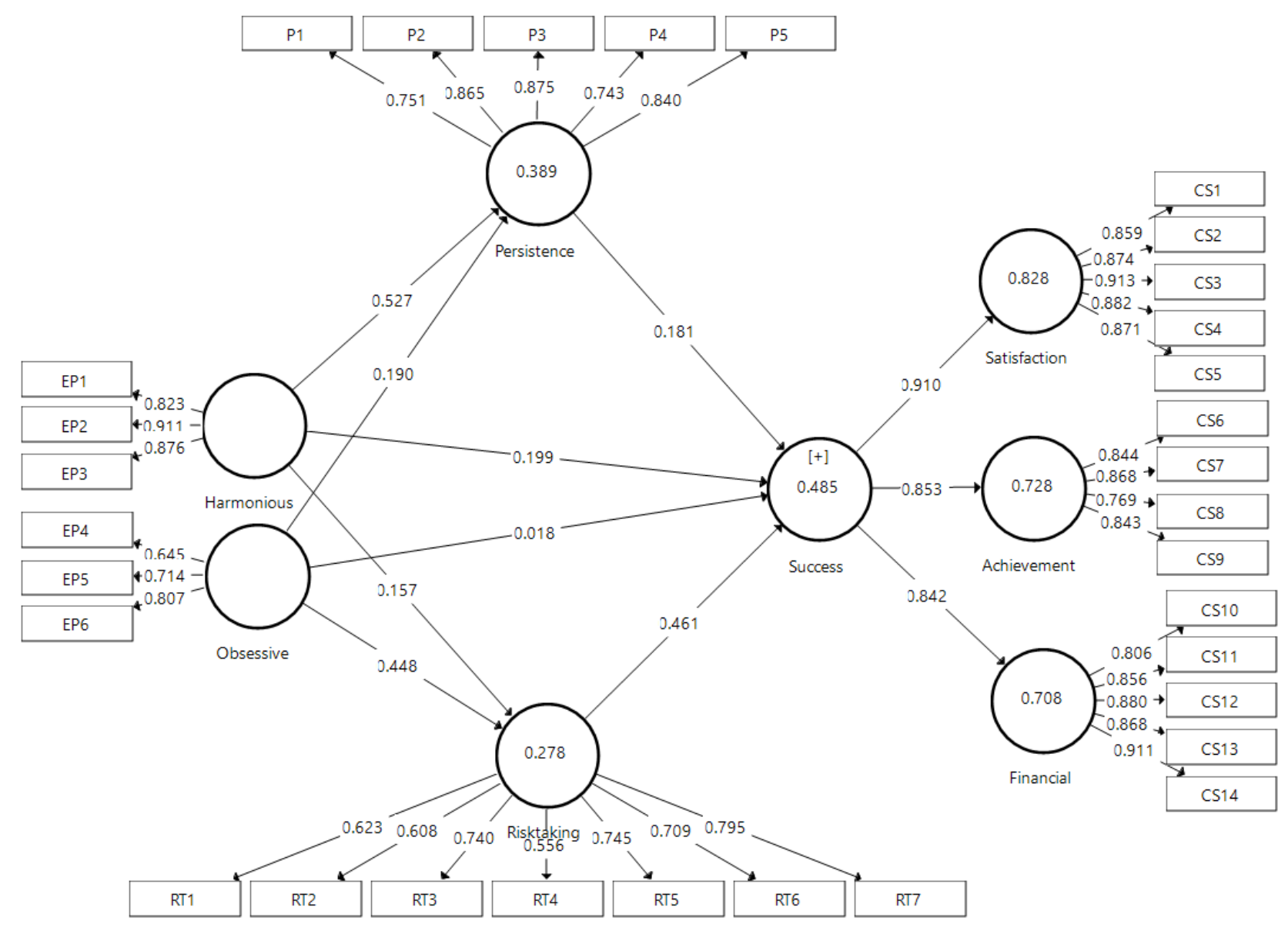

Figure 2. PLS-SEM Measurement model analysis

Source: own elaboration.

The second aim of the study attempted to check if there is a mediating effect by persistence on the passion-success association. The parallel second hypothesis was accepted, revealing that persistence has a complementary and partial mediating role on the passion-success association (standard beta $=0.121$, t-statistic $=2.839, p<0.005$ ). Similarly, persistence had a complementary and partial mediating role on the harmonious passion-success association (standard beta $=0.095$, t-statistic $=$ $2.499, p<0.012$ ). Also, persistence had a complementary and partial mediating role on the obsessive passion-success association (standard beta $=0.034$, $\mathrm{t}$-statistic $=1.974, p<0.048$ ). This was consistent with previous research that discovered a positive and significant persistence-performance association (Baum et al., 2001; Duening et al., 2019) and association between passion and persistence (Cardon et al.,2015; Liang et al., 2018). In this case, the neutral effect of obsessive passion on success due to feeling pressured to perform and rigidity is redeemed by the rise of persistence to achieve the overall entrepreneurial career success.

The third aim of the study attempted to check if there is an intervening effect of risk-taking propensity on the (entrepreneurial passion (EP) and entrepreneurial career success (ECS)) EP-ECS association and was paralleled by the third hypothesis, that risk-taking propensity will mediate the effect of 
entrepreneurial passion (EP) and entrepreneurial career success (ECS), which was accepted. The mediating effect of risk-taking was found to be significant (standard beta $=0.214$, t-statistic $=3.007, p<$ 0.003). Similarly, risk-taking had a complementary and partial mediating role on the harmonious passion-success association (standard beta $=0.072$, t-statistic $=2.410, p<0.016$ ). Also, risk-taking had a complementary and partial mediating role on the obsessive passion-success association (standard beta $=0.207$, t-statistic $=5.224, p=0.000$ ). This is consistent with past work that suggested the possible mediating effect of risk-taking on the passion-success association (Bazerman \& Moore, 1994; Vallerand et al., 2008), and risk-taking relationship with performance (Pratono, 2018; Santos et al., 2020). Since mediating constructs address why particular events take place, the risk-taking propensity experienced by entrepreneurs emerges from the work of obsessive passion to achieve career financial success as shown by work associated with risk-taking and performance (Games \& Rendi, 2019; Wales, 2016).

Table 2. Summary of hypothesis testing

\begin{tabular}{|c|c|c|c|c|}
\hline Paths & Beta & T-value & $P$ value & Decision \\
\hline $\mathrm{H} 1 . \mathrm{EP} \rightarrow \mathrm{ECS}$ & 0.182 & 3.209 & 0.001 & Accept \\
\hline H1a. Harmonious EP $\rightarrow$ ECS & 0.199 & 3.181 & 0.001 & Accept \\
\hline H1b. Obsessive EP $\rightarrow$ ECS & 0.018 & 0.295 & 0.768 & Reject \\
\hline H2. EP $\rightarrow P \rightarrow E C S$ & 0.121 & 2.839 & 0.005 & $\begin{array}{l}\text { Accept (complementary } \\
\text { - partial mediation) }\end{array}$ \\
\hline H2a. Harmonious EP $\rightarrow P \rightarrow$ ECS & 0.095 & 2.499 & 0.012 & $\begin{array}{l}\text { Accept (complementary } \\
\text { - partial mediation) }\end{array}$ \\
\hline $\mathrm{H} 2 \mathrm{~b}$. Obsessive EP $\rightarrow \mathrm{P} \rightarrow \mathrm{ECS}$ & 0.034 & 1.974 & 0.048 & $\begin{array}{l}\text { Accept (indirect-only } \\
\text { - full mediation) }\end{array}$ \\
\hline H3. EP $\rightarrow$ RTP $\rightarrow$ ECS & 0.214 & 3.007 & 0.003 & $\begin{array}{c}\text { Accept (complementary } \\
\text { - partial mediation) }\end{array}$ \\
\hline H3a. Harmonious EP $\rightarrow$ RTP $\rightarrow$ ECS & 0.072 & 2.410 & 0.016 & $\begin{array}{c}\text { Accept (complementary } \\
\text { - partial mediation) }\end{array}$ \\
\hline H3b. Obsessive EP $\rightarrow$ RTP $\rightarrow$ ECS & 0.207 & 5.224 & 0.000 & $\begin{array}{c}\text { Accept (indirect-only } \\
\text { - full mediation) }\end{array}$ \\
\hline
\end{tabular}

Source: own study.

\section{CONCLUSIONS}

The current research bridges a gap in the scarce studies exploring predictors of entrepreneurial career success. The findings uncovered that the two types of passions, namely harmonious and obsessive, can have a strong relationship with success, especially if mediated by persistence and risk-taking propensity. Theoretically, the current model verifies the past finding of a complex link between obsessive passion and performance (Vallerand, 2009). The negative effect of obsessive passion on intrinsic motivation from aggressively competing with others is now verified in entrepreneurship as it was in sports.

An important practical implication of this study concerns, for example, how entrepreneurs may end up working long hours into the night and weekends, and if obsessive passion is involved, entrepreneurs may lose track of time, even ignoring their family call for family time much to the detriment of those relationships. This would not be the situation in harmonious passion because the entrepreneur may leave the activities that he or she is passionate about when necessary and thus avoid conflict between business and family that could spell a disaster. The current findings suggest that with an obsessive passion, an entrepreneur would stand a slim chance of success if not for persistence and risk-taking.

The current study has a limitation regarding the small number of entrepreneurs surveyed in only three states in Malaysia $(n=256)$. Another limitation is the use of self-rating scales, which tend to contribute to response bias. Also, the cross-sectional nature of the study makes the findings difficult to generalise. Future research is advised to include a larger sample and a longitudinal study can offer the advantage of tracking changes over time. One of the limitations of the current study is controlling only for gender and years in business as suggested by (Liu et al., 2018; Ucbasaran et al., 2001). Future studies could also explore the effects of age, size of the venture, and work experience on entrepreneurial career 
success. Previous studies proposed that demographic variables such as age of the business, experience, education, and gender might have an impact on firms taking advantage of opportunities (Chang et al., 2012; Gupta et al., 2014).

\section{REFERENCES}

Adomako, S., Howard Quartey, S., \& Narteh, B. (2016). Entrepreneurial orientation, passion for work, perceived environmental dynamism and firm performance in an emerging economy. Journal of Small Business and Enterprise Development, 23(3), 728-752. https://doi.org/10.1108/JSBED-08-2015-0115

Al Issa, H. (2020). When grit leads to success: the role of individual entrepreneurial orientation. Business: Theory and Practice, 21(2), 643-653. https://doi.org/10.3846/btp.2020.12346

Al Issa, H., Abdelsalam, M.K., \& Omar, M.M.S. (2019). The effect of entrepreneurial self-efficacy on persistence: Do financial literacy and entrepreneurial passion matter?. Polish Journal of Management Studies, 20(2), 6072. https://doi.org/10.17512/pjms.2019.20.2.05

Anderson, B.S., Kreiser, P.M., Kuratko, D.F., Hornsby, J.S., \& Eshima, Y. (2015). Reconceptualizing entrepreneurial orientation. Strategic Management Journal, 36(10), 1579-1596. https://doi.org/10.1002/smj.2298

Avvisati, F., Echazarra, P., Givord, P., \& Schwabe, M. (2020). The programme for international student assessment. Retrieved from <https://www.oecd.org/pisa/publications/PISA2018_CN_MYS.pdf> on August 20, 2020.

Bandura, A. (1986). Social foundations of thought and action. Englewood Cliffs, NJ, 1986, 23-28.

Baum, J.R., \& Locke, E.A. (2004). The relationship of entrepreneurial traits, skill, and motivation to subsequent venture growth. Journal of Applied Psychology, 89(4), 587. https://doi.org/10.1037/0021-9010.89.4.587

Baum, J.R., Locke, E.A., \& Smith, K.G. (2001). A multidimensional model of venture growth. Academy of Management Journal, 44(2), 292-303. https://doi.org/10.5465/3069456

Bazerman, M.H., \& Moore, D.A. (1994). Judgment in managerial decision making. New York: Wiley.

Boone, S., Andries, P., \& Clarysse, B. (2020). Does team entrepreneurial passion matter for relationship conflict and team performance? On the importance of fit between passion focus and venture development stage. Journal of Business Venturing, 35(5), 105984. https://doi.org/10.1016/j.jbusvent.2019.105984

Brown, S.D., Lent, R.W., Telander, K., \& Tramayne, S. (2011). Social cognitive career theory, conscientiousness, and work performance: A meta-analytic path analysis. Journal of Vocational Behavior, 79(1), 81-90. https://doi.org/10.1016/j.jvb.2010.11.009

Brüderl, J., Preisendörfer, P., \& Ziegler, R. (1992). Survival chances of newly founded business organizations. American Sociological Review, 227-242. https://doi.org/10.2307/2096207

Bruin, J. (2006). Newtest: command to compute new test. UCLA: Academic Technology Services, Statistical Consulting Group.

Burke, P.J., \& Reitzes, D.C. (1981). The link between identity and role performance. Social Psychology Quarterly, 83-92. https://doi.org/10.2307/3033704

Caliendo, M., Fossen, F., \& Kritikos, A.S. (2014). Personality characteristics and the decisions to become and stay self-employed. Small Business Economics, 42(4), 787-814. https://doi.org/10.1007/s11187-013-9514-8

Caliendo, M., Goethner, M., \& Weißenberger, M. (2020). Entrepreneurial persistence beyond survival: Measurement and determinants. Journal of Small Business Management, 58(3), 617-647. https://doi.org/10.1080/00472778.2019.1666532

Campos, H.M. (2017). Impact of entrepreneurial passion on entrepreneurial orientation with the mediating role of entrepreneurial alertness for technology-based firms in Mexico. Journal of Small Business and Enterprise Development. https://doi.org/10.1108/JSBED-10-2016-0166

Cardon, M.S., Gregoire, D.A., Stevens, C.E., \& Patel, P.C. (2013). Measuring entrepreneurial passion: Conceptual foundations and scale validation. Journal of Business Venturing, 28(3), 373-396. https://doi.org/10.1016/j.jbusvent.2012.03.003

Cardon, M.S., \& Kirk, C.P. (2015). Entrepreneurial passion as mediator of the self-efficacy to persistence relationship. Entrepreneurship Theory and Practice, 39(5), 1027-1050. https://doi.org/10.1111/etap.12089

Cardon, M.S., Post, C., \& Forster, W.R. (2017). Team entrepreneurial passion: Its emergence and influence in new venture teams. Academy of Management Review, 42(2), 283-305. https://doi.org/10.5465/amr.2014.0356 
Chandler, G.N., \& Jansen, E. (1992). The founder's self-assessed competence and venture performance. Journal of Business Venturing, 7(3), 223-236. https://doi.org/10.1016/0883-9026(92)90028-P

Chang, S., Lin, R., Chang, F., \& Chen, R. (2007). Achieving manufacturing flexibility through entrepreneurial orientation. Industrial Management \& Data Systems, 107(7), 997-1017. https://doi.org/10.1108/02635570710816711

Chen, X.P., Liu, D., \& He, W. (2015). Does passion fuel entrepreneurship and job creativity? A review and preview of passion research. The Oxford Handbook of Creativity, Innovation and Entrepreneurship, 159-175. https://doi.org/10.1093/oxfordhb/9780199927678.013.0004

Chu, H.M., Kara, O., Zhu, X., \& Gok, K. (2011). Chinese entrepreneurs: Motivations, success factors, problems, and business-related stress. Journal of Chinese Entrepreneurship, 3(2), 84-111. https://doi.org/10.1108/17561391111144546

Clark, L.A., \& Watson, D. (1995). Constructing validity: basic issues in objective scale development. Psychological Assessment, 7(3), 309-319. https://doi.org/10.1037/14805-012

Cohen, J. (1988). Statistical power analysis for the behavioural sciences. Mahwah, NJ: Lawrence Erlbaum.

Covin, J.G., \& Slevin, D.P. (1989). Strategic management of small firms in hostile and benign environments. Strategic Management Journal, 10(1), 75-87. https://doi.org/10.1002/smj.4250100107

Deci, E.L., \& Ryan, R.M. (2012). Self-determination theory. In P.A.M. Van Lange, A.W. Kruglanski, \& E.T. Higgins (Eds.), Handbook of Theories of Social Psychology (pp. 416-436). Sage Publications Ltd. https://doi.org/10.4135/9781446249215.n21

Duening, T., Metzger, M., \& Stock, G.N. (2019). Entrepreneurial persistence: Entrepreneurial virtues as dynamic constraints over the entire lifepath. IEEE Engineering Management Review, 47(3), 42-56. https://doi.org/10.1109/EMR.2019.2928788

Efobi, U., \& Orkoh, E. (2018). Analysis of the impacts of entrepreneurship training on growth performance of firms. Journal of Entrepreneurship in Emerging Economies. https://doi.org/10.1108/JEEE-02-2018-0024

Fairoz, F.M., Hirobumi, T., \& Tanaka, Y. (2010). Entrepreneurial orientation and business performance of small and medium scale enterprises of Hambantota District Sri Lanka. Asian Social Science, 6(3), 34. Retrieved from https://www.researchgate.net/profile/Fauzul-Fairoz/publication/41846989_Entrepreneurial_Orientation_and_Business_Performance_of_Small_and_Medium_Scale_Enterprises_of_Hambantota_District_Sri_Lanka/links/0046351aed2962220b000000/Entrepreneurial-Orientation-and-Business-Performance-of-Small-and-Medium-Scale-Enterprises-of-Hambantota-District-Sri-Lanka.pdf on March 03, 2020.

Fornell, C., \& Larcker, D.F. (1981). Evaluating structural equation models with unobservable variables and measurement error. Journal of Marketing Research, 39-50. https://doi.org/10.1177/002224378101800104

Fritsch, M., \& Mueller, P. (2007). The persistence of regional new business formation-activity over time-assessing the potential of policy promotion programs. Journal of Evolutionary Economics, 17(3), 299-315. https://doi.org/10.1007/s00191-007-0056-6

Games, D., \& Rendi, R.P. (2019). The effects of knowledge management and risk taking on SME financial performance in creative industries in an emerging market: the mediating effect of innovation outcomes. Journal of Global Entrepreneurship Research, 9(1), 44. https://doi.org/10.1186/s40497-019-0167-1

Gartner, W.B., Gatewood, E., \& Shaver, K.G. (1991). Reasons for starting a business: Not-so-simple answers to simple questions. In G.E. Hills \& R.W. LaForge (Eds.), Research at the marketing/entrepreneurship interface (pp. 90-101). Chicago: University of Illinois at Chicago.

GEM, (2010). GEM 2010 Global report. Retrieved from https://www.gemconsortium.org/economy-profiles/malaysia-86 on November 5, 2020.

GEM, (2018). GEM 2018 Global report. Retrieved from https://www.gemconsortium.org/report/gem-20172018-global-report on February 25, 2020.

GEM, (2020). GEM 2020 Global report. Retrieved from https://www.gemconsortium.org/latest-global-reports on August 8, 2020.

Goffman, E. (2002). The presentation of self in everyday life. 1959. Garden City, NY, 259.

Greenhaus, J.H., Parasuraman, S., \& Wormley, W.M. (1990). Effects of race on organizational experiences, job performance evaluations, and career outcomes. Academy of Management Journal, 33(1), 64-86. https://doi.org/10.5465/256352

Hair, J.F., Jr, Hult, G.T.M., Ringle, C., \& Sarstedt, M. (2017). A Primer on Partial Least Squares Structural Equation Modeling (PLS-SEM). Los Angeles: Sage Publications. 
Henseler, J., Ringle, C.M., \& Sarstedt, M. (2015). A new criterion for assessing discriminant validity in variancebased structural equation modeling. Journal of the Academy of Marketing Science, 43(1), 115-135. https://doi.org/10.1007/s11747-014-0403-8

Hmieleski, K.M., Corbett, A.C., \& Baron, R.A. (2013). Entrepreneurs' improvisational behavior and firm performance: A study of dispositional and environmental moderators. Strategic Entrepreneurship Journal, 7(2), 138-150. https://doi.org/10.1002/sej.1143

Ho, V.T., \& Pollack, J.M. (2014). Passion isn't always a good thing: Examining entrepreneurs' network centrality and financial performance with a dualistic model of passion. Journal of Management Studies, 51(3), 433-459. https://doi.org/10.1111/joms.12062

Iyortsuun, A.S., Nmadu, M.T., Dakung, R., \& Gajere, M.C. (2019). Entrepreneurial passion and venture performance: a proposed framework. Management Research Review, 42(10), 1133-1147. https://doi.org/10.1108/MRR-10-2018-0382

Karaman, M.A., Vela, J.C., Aguilar, A.A., Saldana, K., \& Montenegro, M.C. (2019). Psychometric properties of USSpanish versions of the grit and resilience scales with a Latinx population. International Journal for the Advancement of Counselling, 41(1), 125-136. https://doi.org/10.1007/s10447-018-9350-2

Kautonen, T., \& Palmroos, J. (2010). The impact of a necessity-based start-up on subsequent entrepreneurial satisfaction. International Entrepreneurship and Management Journal, 6(3), 285-300. https://doi.org/10.1007/s11365-008-0104-1

Kenny, D.A. (2016). Moderation. Retrieved from http://davidakenny.net/cm/moderation.htm\#GG on April 2, 2020.

Kline, R.B. (2011). Principles and practice of structural equation modeling. New York: Guilford Press.

Kollmann, T., Stöckmann, C., Meves, Y., \& Kensbock, J.M. (2017). When members of entrepreneurial teams differ: linking diversity in individual-level entrepreneurial orientation to team performance. Small Business Economics, 48(4), 843-859. https://doi.org/10.1007/s11187-016-9818-6

Kuratko, D.F. (2007). Entrepreneurial leadership in the 21st century: Guest editor's perspective. Journal of Leadership \& Organizational Studies, 13(4), 1-11. https://doi.org/10.1177/10717919070130040201

Lau, V.P., Shaffer, M.A., \& Au, K. (2007). Entrepreneurial career success from a Chinese perspective: conceptualization, operationalization, and validation. Journal of International Business Studies, 38(1), 126-146. https://doi.org/10.1057/palgrave.jibs.8400252

Lavrakas, P.J. (2008). Encyclopedia of survey research methods. Sage Publications. Thousand Oaks.

Lent, R.W., Brown, S.D., \& Hackett, G. (1994). Toward a unifying social cognitive theory of career and academic interest, choice, and performance. Journal of Vocational Behavior, 45(1), 79-122. https://doi.org/10.1006/jvbe.1994.1027

Liang, X., Jiang, J., \& Li, E.Y. (2018). IT-based entrepreneurship in sharing economy: the mediating role of value expectancy in micro-entrepreneur's passion and persistence. International Journal of Information Systems and Change Management, 10(4), 352-373. https://doi.org/10.1504/IJISCM.2018.098400

Lumpkin, G.T., \& Dess, G.G. (1996). Clarifying the entrepreneurial orientation construct and linking it to performance. Academy of Management Review, 21(1), 135-172. https://doi.org/10.5465/amr.1996.9602161568

Ma, C., Gu, J., \& Liu, H. (2017). Entrepreneurs' passion and new venture performance in China. International Entrepreneurship and Management Journal, 13(4), 1043-1068. https://doi.org/10.1007/s11365-017-0435-x

MacKenzie, S.B., \& Podsakoff, P.M. (2012). Common method bias in marketing: Causes, mechanisms, and procedural remedies. Journal of Retailing, 88(4), 542-555. https://doi.org/10.1016/j.jretai.2012.08.001

Marsh, H.W., Vallerand, R.J., Lafrenière, M.A.K., Parker, P., Morin, A.J., Carbonneau, N., ... \& Salah Abduljabbar, A. (2013). Passion: Does one scale fit all? Construct validity of two-factor passion scale and psychometric invariance over different activities and languages. Psychological Assessment, 25(3), 796. https://doi.org/10.1037/a0032573

McCrum-Gardner, E. (2010). Sample size and power calculations made simple. International Journal of Therapy and Rehabilitation, 17(1), 10. https://doi.org/10.12968/ijtr.2010.17.1.45988

McDonald, K.S., \& Hite, L.M. (2008). The next generation of career success: Implications for HRD. Advances in Developing Human Resources, 10(1), 86-103. https://doi.org/10.1177/1523422307310116

Milanesi, M. (2018). Exploring passion in hobby-related entrepreneurship. Evidence from Italian cases. Journal of Business Research, 92, 423-430. https://doi.org/10.1016/j.jbusres.2018.04.020 
Montiel-Campos, H. (2018). The entrepreneurial passion-entrepreneurial alertness relationship: The moderating role of a creative personality. Serbian Journal of Management, 13(2), 263-280. https://doi.org/10.5937/sjm13-16021

Mooradian, T., Matzler, K., Uzelac, B., \& Bauer, F. (2016). Perspiration and inspiration: Grit and innovativeness as antecedents of entrepreneurial success. Journal of Economic Psychology, 56, 232-243. https://doi.org/10.1016/j.joep.2016.08.001

Morgan, R.E., \& Strong, C.A. (2003). Business performance and dimensions of strategic orientation. Journal of Business Research, 56(3), 163-176. https://doi.org/10.1016/S0148-2963(01)00218-1

Mueller, B.A., Wolfe, M.T., \& Syed, I. (2017). Passion and grit: An exploration of the pathways leading to venture success. Journal of Business Venturing, 32(3), 260-279. https://doi.org/10.1016/j.jbusvent.2017.02.001

Murnieks, C.Y., Mosakowski, E., \& Cardon, M.S. (2014). Pathways of passion: Identity centrality, passion, and behavior among entrepreneurs. Journal of Management, 40(6), 1583-1606. https://doi.org/10.1177/0149206311433855

Murnieks, C.Y., Cardon, M.S., \& Haynie, J.M. (2020). Fueling the fire: Examining identity centrality, affective interpersonal commitment and gender as drivers of entrepreneurial passion. Journal of Business Venturing, 35(1), 105909. https://doi.org/10.1016/j.jbusvent.2018.10.007

Musa, D., Ghani, A.A., \& Ahmad, S. (2014). Linking entrepreneurial orientation and business performance: The examination toward performance of cooperatives firms in Northern Region of Peninsular Malaysia. International Journal of Business and Technopreneurship, 4(2), 247-264. Retrieved from http://dspace.unimap.edu.my:80/xmlui/handle/123456789/40042 on March 3, 2020.

Palalic, R., \& Busatlic, S. (2015). Exploratory research on relationship between entrepreneurial orientation dimensions and business performance and growth of fast and slow growing small and medium enterprises in Bosnia and Herzegovina. International Journal of Business and Management, 10(2), 15. Retrieved from https://www.researchgate.net/profile/Ramo-Palalic/publication/273160799_Exploratory_Research_on_Relationship_between_Entrepreneurial_Orientation_Dimensions_and_Business_Performance_and_Growth_of_Fast_and_Slow_Growing_Small_and_Medium_Enterprises_in_Bosnia_and_Herzegovina/links/5680f5bb08ae1975838dde33/Exploratory-Research-on-Relationship-between-Entrepreneurial-Orientation-Dimensions-and-Business-Performance-and-Growth-of-Fast-and-Slow-Growing-Small-andMedium-Enterprises-in-Bosnia-and-Herzegovina.pdf on March 3, 2020.

Pallant, J. (2013). SPSS survival manual: A step by step guide to data analysis using SPSS for windows (4 ${ }^{\text {th }}$ ed.). England, UK: McGraw Hill Open University Press.

Poczwardowski, A., Diehl, B., O'Neil, A., Cote, T., \& Haberl, P. (2014). Successful transitions to the Olympic Training Center, Colorado Springs: A mixed-method exploration with six resident-athletes. Journal of Applied Sport Psychology, 26(1), 33-51. https://doi.org/10.1080/10413200.2013.773950

Pratono, A.H. (2018). Does firm performance increase with risk-taking behavior under information technological turbulence? Empirical evidence from Indonesian SMEs. Journal of Risk Finance, 19(4), 361-378. https://doi.org/10.1108/JRF-10-2017-0170

Priyono, P. (2017). Effect of Social Capital to the Life Satisfaction of Academic Personnel in the Higher Education Through the Human Capital and Institutional Model. International Journal of Economic Research, 14(7), 253276. Retrieved from http://eprints.binadarma.ac.id/id/eprint/3310 on March 3, 2020.

Salisu, I., Hashim, N., Ismail, K., \& Isa, F.M. (2017). Mediating effect of entrepreneurial career resilience between entrepreneurial career commitment and entrepreneurial career success. International Journal of Economic Research, 14(19), 231-251. Retrieved from https://www.researchgate.net/profile/Isyaku-Salisu/publication/322736940_Mediating_effect_of_entrepreneurial_career_resilience_between_entrepreneurial_career_commitment_and_entrepreneurial_career_success/links/5ba5e90fa6fdccd3cb69ed2c/Mediating-effect-of-entrepreneurial-career-resilience-between-entrepreneurial-career-commitment-and-entrepreneurial-career-success.pdf on March 3, 2020.

Salisu, I., Hashim, N., Mashi, M.S., \& Aliyu, H.G. (2020). Perseverance of effort and consistency of interest for entrepreneurial career success: Does resilience matter?. Journal of Entrepreneurship in Emerging Economies, 12(2), 279-304. https://doi.org/10.1108/JEEE-02-2019-0025

Santos, G., Marques, C.S., \& Ferreira, J.J. (2020). Passion and perseverance as two new dimensions of an Individual Entrepreneurial Orientation scale. Journal of Business Research, 112, 190-199. https://doi.org/10.1016/j.jbusres.2020.03.016

Shane, S., Locke, E.A., \& Collins, C.J. (2003). Entrepreneurial motivation. Human Resource Management Review, 13(2), 257-279. https://doi.org/10.1016/S1053-4822(03)00017-2 
Sheldon, K.M., Elliot, A.J., Ryan, R.M., Chirkov, V., Kim, Y., Wu, C., ... \& Sun, Z. (2004). Self-concordance and subjective well-being in four cultures. Journal of Cross-cultural Psychology, 35(2), 209-223. https://doi.org/10.1177/0022022103262245

Shrader, R.C., Oviatt, B.M., \& McDougall, P.P. (2000). How new ventures exploit trade-offs among international risk factors: Lessons for the accelerated internationalization of the 21st century. Academy of Management Journal, 43(6), 1227-1247. https://doi.org/10.5465/1556347

Stroe, S., Parida, V., \& Wincent, J. (2018). Effectuation or causation: An fsQCA analysis of entrepreneurial passion, risk perception, and self-efficacy. Journal of Business Research, 89, 265-272. https://doi.org/10.1016/j.jbusres.2018.01.035

Tabachnick, B.G., \& Fidell, L.S. (2007). Using multivariate statistics (5th edn). Boston, MA: Pearson Education.

Tan, J., \& Litsschert, R.J. (1994). Environment-strategy relationship and its performance implications: An empirical study of the Chinese electronics industry. Strategic Management Journal, 15(1), 1-20. https://doi.org/10.1002/smj.4250150102

Thorgren, S., \& Wincent, J. (2015). Passion and habitual entrepreneurship. International Small Business Journal, 33(2), 216-227. https://doi.org/10.1177/0266242613487085

Ucbasaran, D., Westhead, P., \& Wright, M. (2001). The focus of entrepreneurial research: contextual and process issues. Entrepreneurship Theory and Practice, 25(4), 57-80. https://doi.org/10.1177/104225870102500405

Vallerand, R.J., Mageau, G.A., Elliot, A.J., Dumais, A., Demers, M.A., \& Rousseau, F. (2008). Passion and performance attainment in sport. Psychology of Sport and Exercise, 9(3), 373-392. https://doi.org/10.1016/j.psychsport.2007.05.003

Vallerand, R.J. (2008). On the psychology of passion: In search of what makes people's lives most worth living. Canadian Psychology/Psychologie Canadienne, 49(1), 1. https://doi.org/10.1037/0708-5591.49.1.1

Vallerand, R.J., Blanchard, C., Mageau, G.A., Koestner, R., Ratelle, C., Léonard, M., ... \& Marsolais, J. (2003). Les passions de l'ame: on obsessive and harmonious passion. Journal of Personality and Social Psychology, 85(4), 756. https://doi.org/10.1037/0022-3514.85.4.756

Vallerand, R.J. (2016). The dualistic model of passion: theory, research, and implications for the field of education. In W. Liu, J. Wang, \& R. Ryan (Eds.), Building autonomous learners (pp. 31-58). Singapore: Springer. https://doi.org/10.1007/978-981-287-630-0_3

Van Scotter, J.R., \& Garg, S. (2019). Entrepreneurial Tenacity and Self-Efficacy Effects on Persisting Across Industry Contexts. Contemporary Management Research, 15(3), 147-173. https://doi.org/10.7903/cmr.19501

Venkatraman, N. (1989). Strategic orientation of business enterprises: The construct, dimensionality, and measurement. Management Science, 35(8), 942-962. https://doi.org/10.1287/mnsc.35.8.942

Wach, D., Stephan, U., Marjan, J.G., \& Wegge, J. (2018). Entrepreneurs' achieved success: developing a multi-faceted measure. International Entrepreneurship and Management Journal, 1-29. https://doi.org/10.1007/s11365-018-0532-5

Wales, W.J. (2016). Entrepreneurial orientation: A review and synthesis of promising research directions. International Small Business Journal, 34(1), 3-15. https://doi.org/10.1177/0266242615613840

Wu, S., Matthews, L., \& Dagher, G.K. (2007). Need for achievement, business goals, and entrepreneurial persistence. Management Research News, 30(12), 928-941. https://doi.org/10.1108/01409170710833358

Zahra, S.A. (2018). Entrepreneurial risk taking in family firms: The wellspring of the regenerative capability. Family Business Review, 31(2), 216-226. https://doi.org/10.1177/0894486518776871

Zhao, Y., Li, Y., Lee, S.H., \& Bo Chen, L. (2011). Entrepreneurial orientation, organizational learning, and performance: Evidence from China. Entrepreneurship Theory and Practice, 35(2), 293-317. https://doi.org/10.1111/j.1540-6520.2009.00359.x 


\section{Author}

\section{Hussein-Elhakim Al Issa}

Assistant Professor of Management at A'Sharqiyah University (Oman). He received his PhD in Management from Universiti Utara (Malaysia). His research interests centre on the application of strategy and business concepts to social change. His work has been published and presented at national and international conferences and research colloquia, and he currently has several manuscripts under review at leading research journals.

Correspondence to: Dr Hussein-Elhakim Al Issa, Department of Management, College of Business Administration, A'Sharqiyah University, P.O.Box 42, Ibra, Postal Code 400, Sultanate of Oman, e-mail: hussein.alissa@asu.edu.om ORCID (1) http://orcid.org/0000-0002-3214-9745

\section{Acknowledgements and Financial Disclosure}

I would like to express my gratitude to the participants involved in this research. There are no financial conflicts of interest to disclose.

\section{Conflict of Interest}

The author declares that the research was conducted in the absence of any commercial or financial relationships that could be construed as a potential conflict of interest.

\section{Copyright and License}

This article is published under the terms of the Creative Commons

Attribution - NoDerivs (CC BY-ND 4.0) License

http://creativecommons.org/licenses/by-nd/4.0/

Published by Cracow University of Economics - Krakow, Poland 